\title{
Oncomouse hearing ends up in confusion
}

Munich. An appeal hearing held to cxamine challenges to the first European-wide patent on an animal - Harvard University's socalled 'oncomouse' - broke up in disarray last week, when the opposition board of the European Patent Office (EPO), which should have given immediate judgement, found itself unable to answer some of the arguments raised against the patent.

The patent in question was granted in 1991 to Harvard on a mouse whose susceptibility to cancer is increased by the insertion of oncogenes into its genome. It had been challenged by a number of animal rights and environmentalist groups as conflicting with a clause in the European Patent Convention (EPC) that forbids patents on inventions considered to be contrary to public morality.

But after three days of listening to evidence related to 17 different appeals against the patent, the board, apparently thrown into uncertainty by arguments put forward by opponent groups at the oral hearing to back up their earlier written claims, unexpectedly drew the hearing to a close

The board's declaration that the proceedings would continue only in writing angered the lawyers of both opponents and patent holders, who argued that the decision conflicts with the EPO's established procedures. No timetable was given for the written proceedings, or the likely date of a decision.

The EPO appears to have been embarrassed by the breakdown of its procedures during such a highly visible case. But its eventual verdict is still keenly awaited. Since the oncomouse patent application was filed with the EPO in 1985, the office has received more than 300 applications for patents on animals. Only three - including the oncomouse - have so far been granted. Decisions on the remainder are awaiting the outcome of the oncomouse case.

In initially granting the oncomouse patent, the EPO, which was set up to carry out the procedures established in the EPC, interpreted the morality requirement to mean that benefits to humans must outweigh the harm to animals, and decided in favour of the value of the oncomouse as an animal model for human cancer.

But this interpretation has been challenged by various pressure groups, including in particular two British groups - Compassion in World Farming (CIWF) and the British Union for the Abolition of Antivivisection - and the mainly German group, Kein Patent auf Leben (No Patents on Life).

In addition to the claim that the oncomouse patent conflicts with the morality clause, these groups argue that, even within the EPO's own rules, the patent is invalid. One reason, they say, is its breadth, as the patent covers any mammal genetically engineered for increased susceptibility to cancer.

The groups argue, for example, that demands for the patent to cover an 'oncogiraffe' should be rejected on three related grounds. Firstly, the patent discloses insufficient information to allow an independent expert to create such a transgenic animal. Second, there is no moral justification for an 'oncogiraffe', as it could not be used as an experimental animal, and therefore could not be considered beneficial to humans. And third, there is no known industrial application for such an animal.

To the surprise of participants, who had expected a clear decision at the end of the week, the board of appeals appeared to indicate in the middle of last week's hearing that this claim had some legitimacy. It asked both sides for comments on a proposal that the patent should be restricted either to experimental animals or to rodents.

"This is the first indication we have had that the EPO thinks there is substance in the opponents' claims," says Peter Stevenson, a

\section{Patently a matter of principle, not profit}

Munich. As far as industry is concerned, last week's opposition hearing on the Harvard oncomouse patent (see above) was very much a battle of principle, rather than a defence of the profitability of the oncomouse itself, which does not appear to have been the commercial success originally expected.

Sales of the oncomouse were licensed to Dupont, the Delaware-based chemical company which subsidized the research leading to its development by scientists at Harvard University. Dupont took up the licensing rights to which it was entitled under its funding agreement with Harvard.

But a spokeswoman for the company says that Dupont later changed its mind about the value of licensing and sublicensing sales of the animal. "In order to bring therapeutics faster to the market there was more merit in having the animals made widely available," she says, adding that the company often gave away oncomice to university research groups free of charge.

The university will not say how much it has received in royalties from oncomouse sales. Meanwhile Dupont will soon be free of the whole issue. It is selling off its medical products division to concentrate on its core chemicals activities - and the sale will include its rights to the oncomouse.

A. A.

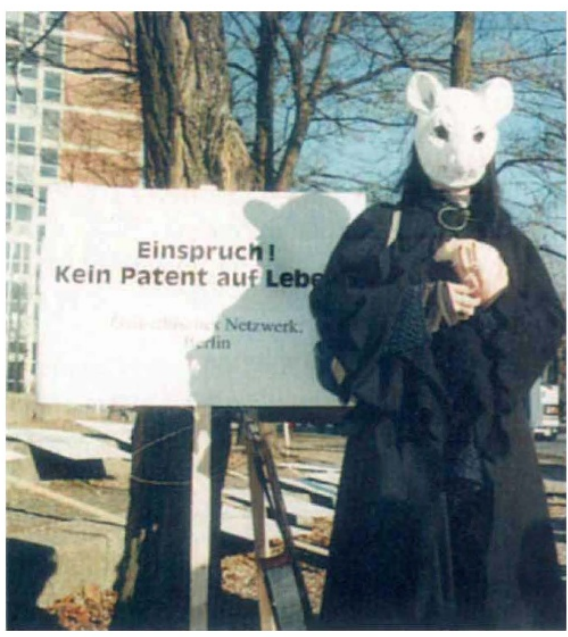

Not a squeak: protest at the patent hearing. No timetable has been set for the ruling.

lawyer with CIWF. But, he adds, such a restriction would be only a partial victory for the opposition groups, whose main goal is that the patent should be revoked in full.

Another argument used by the opponents was that the oncomouse should be seen as an animal species, and thus as a collection of animal varieties. As 'varieties' of both animals and plants are excluded from patentability by the EPC, they claim, that in itself makes the oncomouse patent invalid. Lawyers for Harvard maintain that the two taxonomic levels can and should be distinguished - a position that has until very recently been shared by the EPO.

Now, however, this broader issue of the scope of the 'varieties' exclusion is under consideration by the EPO's highest legal authority, the Enlarged Board of Appeals, which is considering a patent granted to Plant Genetics Systems (PGS) of Ghent, Belgium, on a procedure for producing herbicide-resistant plants.

The PGS patent was partly revoked in February, when an EPO board of appeals ruled that it could not cover plants and seeds arising from the process (see Nature 374, 8; 1995). This was the first time that the EPC had been interpreted as meaning that plants themselves, as well as plant varieties, were not patentable.

But Paul Braendli, the president of the EPO, has asked for this decision to be considered by the office's Enlarged Board of Appeals, as it appears to conflict with previous rulings on the patentability of plants.

Braendli has also asked patent examiners not to use the PGS decision as a precedent before the higher board gives a final ruling. But in preliminary written comments on the opposition claims, published recently, the oncomouse board of appeal said it would not wait for the Enlarged Board of Appeal's parallel judgement on plants, which could take many months.

Alison Abbott 